\title{
Bağlılık Boyutlarının Tükenmişlik Boyutları Üzerindeki Etkisinin İncelenmesi
}

\author{
Yrd. Doç. Dr. Sema POLATCI \\ Gaziosmanpaşa Üniversitesi, I.I.I.B.F., İsletme Bölümü, TOKAT \\ Prof. Dr. Kadir ARDIÇ \\ Sakarya Üniversitesi, İșletme Fakültesi, İnsan Kaynakları Yönetimi Bölümü, SAKARYA
}

BIm. Uzm. Gülçin TÜRKAN

$\ddot{O Z Z E T}$

Bu çalışmanın amacl genel kabul görmüş örgütsel bağlllık yazınına göre üç boyutta incelenen bağlllık türleri olan duygusal, devam ve normatif bağlllı̆̆ın, tükenmişlik düzeyi ve onun alt boyutları olan duygusal tükenme, duyarsızlaşma ve kişisel başarlda düşme üzerindeki etkisinin incelenmesidir. Bu amaç kapsamında çalışmada hem örgütsel bağlllık hem de tükenmişlik değişkenleri alt boyutlar bağlamında ele alınmış ve bir model geliştirilmiştir. Araştırmanın örneklemi özel bir hastanede görev yapan 192 sağllk personelinden oluşmaktadır. Araştırma sonucunda elde edilen bulgulara göre duygusal ve normatif bağlllı̆̆ı artması duygusal tükenme ve duyarsızlaşmanın azalmasına, kişisel başarı hissinin ise artmasına neden olmaktadır. Diğer yandan bir diğer örgütsel bağlllık alt boyutu olan devam bağlllığının artması ise tam tersine duygusal tükenme ve duyarsızlaşmanın artmasına, kişisel başarı hissinin ise azalmasına neden olmaktadır.

Anahtar Kelimeler: Duygusal bă̆gllık, Devam bağlllı̆̆l, Normatif bağglllık, Duygusal tükenme, Duyarsızlaşma, Kişisel başarı

JEL Siniflaması: M10, M12, M54

\section{An Analysis about The Effects of Commitment Dimensions on The Burnout Dimensions}

ABSTRACT

The purpose of this study was to explore the effect of commitment dimensions - affective commitment, continuance commitment, normative commitment- on the burnout dimensions emotional exhaustion, depersonalization, personal accomplishment. Within this aim a model was developed which handle the dimensions of organizational commitment and burnout. The sample of this study consists of 192 health personnel working in a private hospital. According to the results increase in affective and normative commitment cause decrease in emotional exhaustion and depersonalization, also increase in personal accomplishment. On the other hand increase in continuance commitment causes increase in emotional exhaustion and depersonalization, also decrease in personal accomplishment.

Key Words: Affective commitment, Continuance commitment, Normative commitment, Emotional exhaustion, Depersonalization, Personal accomplishment

JEL Classification: M10, M12, M54

\section{Giriş}

Örgütsel davranış yazını pozitif ve negatif pek çok kavramı içermektedir. En çok araştırılan pozitif kavramların başında örgütsel bağlılık, en çok araştırılan negatif kavramların başında ise tükenmişlik gelmektedir. Bunun nedeni örgüt ile işgören arasındaki etkileşimin kalitesinden kaynaklanan örgüte bağlılık ve tükenmişliğin işgöreni ve dolayısıyla da örgütü ciddi anlamda etkilemesidir. 
Yazındaki çalışmalarda sıkça örgütsel bağl1lık ve tükenmişlik arasındaki ilişki araştırılmıştır (Leiter ve Maslach, 1988; Liu, 1996; Güneş, vd., 2009; Çetin, vd., 2011). Ancak bahsi geçen araştırmalarda genellikle hem örgütsel bağl1lık ve tükenmişlik tek boyutlu olarak ele alınmış, hem de değişkenler arasındaki ilişki incelenirken birinin diğerine etkisi üzerinde durulmamıştır. Bu çalışmada örgütsel bağl1lık ve tükenmişliğin boyutları üzerinden analiz yapılmış ve örgütsel bağlılık boyutlarının tükenmişlik boyutları üzerindeki etkisi araştırılmıştır. Etkin insan kaynakları çalışmaları için bu iki değişken arasındaki etkileşimin özellikle boyutlar bazında incelenmesinin önemli olduğu düşünülmektedir.

\section{I. Örgütsel Bağlılık ve Boyutları}

Örgütsel davranış yazınında sıkça işlenen kavramlardan birisi olan örgütsel bağlılık kavramı, pek çok araştırmaya konu olmuştur. Kavramın yazında sıkça kullanılmasının nedeni, işgören davranışlarını olumlu yönde etkileyen bu kavramın, hem bireysel hem de örgütsel açıdan pozitif etkiler yaratmasıdır.

Örgütsel bağlılık kavramı ile ilgili yazında pek çok tanım bulunmaktadır. Morrow (1983: 41) örgütsel bağlılı̆̆ psikolojik bir faktör olarak ifade etmiş, işgörenlerin örgütte kalma, örgüt için çaba gösterme ve örgütün amaç ve değerlerini benimsemesi olarak tanımlamıştır. Buradan hareketle örgütsel bağlılığın, işgörenin örgüte karşı olan sadakati ve görev yaptığı örgütün başarılı olması için gösterdiği çaba ile ilişkili bir tutum olduğunu söylemek mümkündür. $\mathrm{Bu}$ açıdan bakıldığında örgütsel bağlılık davranış biçiminin, işgörenlerin amirlerinin söylediklerini yapmaları şeklinde tanımlanabilen uyma davranışından farklı olduğu ortadadır (Eren, 2010: 555).

Örgütsel bağll1ık yazını incelendiğinde örgütsel bağlıllğın nasıl geliştiği konusunda iki farklı görüş dikkat çekmektedir. Mowday ve arkadaşları (1982) bu görüşleri temel alarak, örgütsel bağlllı̆̆ iki boyutta ele almıştır. Bu boyutlar tutumsal bağl1lık ve davranışsal bağglı1ıtır. Tutumsal bağlılık işgörenin çalışma ortamını değerlendirmesi sonucunda oluşan ve onu örgüte bağlayan duygusal bir tepki iken; davranışsal bağl1lık işgörenin geçmiş deneyimleri ve örgüte uyum sağlama durumlarına göre örgütlerine bağlı hale gelmelerini ifade etmektedir.

Meyer ve Allen (1984; 1991; Allen ve Meyer 1990) ise hem örgütsel bağl1lık konusundaki çalışmaları incelemiş, hem de kendilerinin yürüttükleri araştırmalar sonucunda, örgütsel bağlllık ile ilgili geliştirilmiş olan kavramsal çerçevenin, kavramın tam olarak açılanabilmesi için yeterli gelmediğini savunmuşlardır. Onlara göre örgütsel bağlllık psikolojik bir kavramdır ve üç ana boyutta incelenmelidir. İlk olarak Meyer ve Allen tarafından geliştirilmiş olan ve günümüzde örgütsel bağlılık araştırmalarında sıklıkla kullanılmakta olan bu boyutlar duygusal bağl1lık, devam bağl11 ı̆g ve normatif bağl11ıktır.

Duygusal Bağlllık: Psikolojik bir bağl1lık türü olan duygusal bağlılık, işgörenlerin örgütün üyesi olmaktan dolayı mutlu olmasını sağlayan kişisel ve örgütsel değerlerin birbirleriyle uyumlu olması sonucu oluşmaktadır. İşgörenler kendi değerleri, fikirleri, kültürü, tutumları gibi özelliklerinin; örgütün değerleri, fikirleri, kültürü, tutumları gibi özellikleriyle ortak olduğunu algıladıklarında örgütlerine duygusal olarak bağlanmaktadırlar (Demirel, 2009:117; Ensher vd. 
2001: 56). Araştırmalar işle ya da örgütle ilgili davranışları açıklamada en güçlü bağl1lık boyutunun duygusal bağl1lık olduğunu göstermektedir (Gümüşlüoğlu ve Aygün, 2010:22).

Devam Bağlllı̆̆ı: İşgörenin örgütte çalıştığı süre içerisinde harcadığ1 çaba, zaman ve emek, edindiği statü, para gibi kazanımlarını örgütten ayrılması sonucunda kaybedeceği düşüncesiyle oluşan bağl1lıktır (Karahan, 2008:235; Yılmazer, 2010:238; Boylu vd., 2007:58). Diğer bir deyişle devam bağl1lığı, işgörenin örgütten ayrılmanın beraberinde getireceği maliyeti yani, olumsuzlukları dikkate alması ve bir zorunluluk olarak örgütte kalmaya devam etmesi olarak tanımlanabilir (Meyer ve Allen, 1997: 11).

Normatif Bağlllık: Ahlaki bir bağl1lık türü olan normatif bağl1lık, örgütte kalmaya yönelik algılanan zorunluluğu ifade etmektedir (Çakar ve Ceylan 2005:56). Bu bağlilık türü işgörenin sadakat, görev, sorumluluk ve zorunluluk gibi hislerinden dolayı örgütte kalması ile ilişkilidir. Normatif bağlılığı yüksek olan bireyler, örgütte kalma veya örgüte bağlılık göstermenin doğru bir davranış olduğunu hissettikleri için örgüt üyeliğini sürdürmektedirler (Göksel ve Aydıntan, 2012: 253).

Genel bir bakış açısı ile üç bağl1lık türü incelendiğinde, duygusal bağlılığın isteğe, devam bağlılığının gereksinime, normatif bağlılığın ise yükümlülüğge bağlı bir örgütte kalma güdüsü olduğunu söylemek mümkündür (Obeng ve Ugboro, 2003).

\section{Tükenmişlik ve Boyutları}

Son zamanlarda gündemdeki isimlerden de sskça duyduğumuz bir iş hastalığı olan tükenmişlik sendromu, konusu itibariyle insanların işleri nedeniyle kurdukları ilişkiler ve bu ilişkilerin kötü gitmesiyle ortaya çıkan sorunlarla ilgilidir. İlk kez 1974 yılında Herbert Freudenberger tarafından "başarısız olma, yıpranma, enerji ve gücün azalması veya tatmin edilemeyen istekler sonucunda bireyin iç kaynaklarında meydana gelen tükenme durumu" şeklinde tanımlanmıştır (Freudenberger, 1974:159).

Maslach ve Jackson (1981)'a göre tükenmişlik, yoğun olarak insanlarla yüz yüze iletişim gerektiren mesleklerde daha fazla görülmektedir. $\mathrm{Bu}$ tarz mesleklerde, insanlara karşı duyulan sorumluluğun, nesnelere karşı duyulan sorumluluktan daha fazla olması nedeniyle, bu kişilerde tükenme riskinin daha yüksek olduğu çeşitli araştırmalarla ortaya konmuştur (Truch, 1980; akt. Ensari ve Tuzcuoğlu, 1995). Bu nedenle tükenmişlik; hizmet sektörü çalışanları olan doktorlar, hemşireler, hastabakıcılar, avukatlar, öğretmenler, akademisyenler, polisler, bankacılar, sosyal hizmet görevlileri, çocuk bakıcıları, çeşitli işletmelerin müşteri hizmetleri temsilcileri ve herhangi bir alanda yönetici kademesinde görev yapanlarda daha fazla görülmektedir (Maslach ve Zimbardo, 1982; Ensari ve Tuzcuoğlu, 1995; Ergin, 1995; Aslan, vd, 2005; Gündüz, vd., 2007; Campana ve Hammoud, 2014).

Tükenmişliğin en yaygın ve kabul gören tanımı, Christina Maslach tarafından yapılmıştır. Maslach tükenmişliği "işi gereği insanlarla yoğun bir ilişki içerisinde olan bireylerde görülen duygusal tükenme, duyarsızlaşma ve düşük 
kişisel başarı hissi" olarak tanımlamıştır (Maslach ve Zimbardo, 1982:3; Maslach, Schaufeli ve Leiter, 2001:399). Şekil 1, Maslach'1n tükenmişlik modelindeki birbirini izleyen aşamaları göstermektedir.

$$
+ \text { Duygusal Tükenme } \longrightarrow \quad+\text { Duyarsızlaşma } \quad \longrightarrow \quad \text { - Kişisel Başarı }
$$

Şekil 1. Maslach'ın Tükenmişlik Modeli

Maslach ve Jackson (1986) tükenmişliği duygusal tükenme, duyarsızlaşma ve kişisel başarıda düşmeden oluşan, "üç bileşenli bir psikolojik sendrom" şeklinde ifade etmişlerdir. Buna göre tükenmişlik yaşayan bireyde öncelikle duygusal tükenme, daha sonra duyarsılaşma ve son olarak da kişisel başarıda düşme görülmektedir.

Duygusal Tükenme: Tükenmişliğin bireysel stres boyutunu temsil etmektedir. En önemli boyut olarak kabul edilen duygusal tükenme, aynı zamanda tükenmişliğin başlangıcı ve en net belirtisi olarak da görülmektedir (Maslach, Schaufeli ve Leiter, 2001). Duygusal tükenmenin temel nedeni aşırı iş yükü, işte yaşanan kişilerarası anlaşmazlıklar ve olumsuz çalışma koşullarıdır. Duygusal tükenme yaşayan işgörenler kendilerini bitkin ve kullanılmış hissetmekte, enerjilerini geri kazanmak için hiçbir kaynak bulamamaktadırlar (Maslach ve Goldberg, 1998) ve bunların bir sonucu olarak hizmet verdikleri kişilere geçmişte olduğu kadar verici ve ilgili davranmadıklarını hissetmektedirler. Tükenmişlik sendromu yaşayan bireylerin, durumlarını tanımlarken en çok kullandıkları belirtiler duygusal tükenme boyutu ile ilgili belirtilerdir. Tükenmişliğin üç boyutu arasında en çok rapor edilen ve en çok analiz edilen de duygusal tükenme boyutudur (Shirom, 1989).

Duyarsızlaşma: Tükenmişliğin kişilerarası iletişim boyutunu temsil etmektedir (Maslach ve Goldberg, 1998). Bu boyut sonucunda kişilerarası ilişkilerde meydana gelen bozulmalar, tükenmişliği bireysel bir problem olmaktan çıkarıp, örgüt geneline yayılan salgın bir hastalık haline getirmektedir. Bireyin işi gereği karşılaştı̆̆ diğer insanlara ve işine karşı soğuk, ilgisiz, katı, hatta insancıl olmayan tutumlar geliştirmesi olarak tanımlanabilen duyarsızlaşma, işe yönelik idealizmde önemli ölçüde azalmaya (Maslach, Schaufeli ve Leiter, 2001) ve hizmet verilen kişilere karşı olumsuz tutumlara neden olmaktadır. Duyarsızlaşma bir açıdan insanların kendilerini, tükenme ve hayal kırıklığından koruma ve yaşadıkları psikolojik gerginlikten bilinçli bir şekilde uzaklaştırabilmek için uyguladıkları bir savunma stratejisidir. Duyarsızlaşma yaşayan birey, psikolojik açıdan aldığı zararı azaltabilmek için insanlarla arasına bir tür "duygusal tampon" oluşturmaktadır (Maslach ve Goldberg, 1998).

Kişisel Başart: Tükenmişliğin kişisel gelişme boyutunu temsil etmektedir. Düşük kişisel başarı hissi tükenmişliğin bir parçasını oluşturmaktadır ve çoğu zaman diğer iki boyutun bir sonucu olarak görülmektedir. Bu boyut kişinin kendisini olumsuz değerlendirme eğiliminde olmasını ifade etmektedir (Maslach, Schaufeli ve Leiter, 2001). Bireyin başkaları hakkında geliştirdiği 
olumsuz düşünceler, bir süre sonra kendisi için de olumsuz düşünceler geliştirmesine neden olmaktadır. Tükenmişlik yaşayan kişi işinde ilerleyemediğini, boşuna çalıştı̆̆ını, zaman harcadığını düşünerek suçluluk ve yetersizlik duygularına kapılmakta (Silah, 2005: 163), kendisini çaresiz hissederek yeteneklerini sorgulamaya başlamakta ve bu durum kişisel başarıda düşüşe neden olmaktadır (Cordes, Dougherty ve Blum, 1997).

\section{III. Örgütsel Bağlılık ve Tükenmişlik Arasındaki İlişkiler}

Örgütsel bağlılık ve tükenmişlik değişkenlerini konu alan araştırmaları farklı başlıklar altında toplamak mümkündür. Bu araştırmaların bir kısmı örgütsel bağlılı̆̆1 tek boyutlu olarak ele almış ve örgütsel bağl1lığın tükenmişlik ve boyutları ile ilişkisini incelemiş̧tir. Bu yöndeki araştırmalarda genel olarak örgütsel bağlılık ile tükenmişlik arasında negatif yönlü bir ilişki olduğu tespit edilmiştir (Leiter ve Maslach, 1988; Liu, 1996). Bununla birlikte çalışmaların bazıları örgütsel bağlılığın daha çok duygusal tükenme ve kişisel başarıda düşme boyutu ile ilişkili olduğunu (Leiter ve Maslach, 1988: 306; Liu, 1996: 86), bazıları ise örgütsel bağlılığın sadece tükenmişliğin kişisel başarıda düşme boyutu ile ilişkili olduğunu (Haley, 2003: 61) savunmaktadır.

Konu ile ilgili araştırmaların bazıları ise örgütsel bağlılık ve tükenmişlik değişkenlerinin her ikisini de boyutlar bazında ele almış ve bu iki değişkenin boyutları arasındaki ilişkileri incelemiştir. Örneğin Güneş ve arkadaşları (2009)'nın bir kamu üniversitesi personeli üzerinde yaptıkları araştırmada tükenmişlik boyutlarından duygusal tükenmenin duygusal bağl1lık ve normatif bağl1lık ile, duyarsızlaşmanın normatif bağl1lık ile ve kişisel başarının devam bağl1lı̆̆1 ile negatif yönde ilişkili olduğu belirlenmiştir. Diğer yandan Chuo (2003) duygusal bağlılıkla duyarsızlaşma arasında, devam bağlılığı ile kişisel başarı arasında ve normatif bağlılıkla duygusal tükenme ve duyarsızlaşma arasında negatif yönlü ilişkiler tespit etmiştir. Çetin ve arkadaşları (2011) ise duygusal ve normatif bağlılığın tüm tükenmişlik boyutları ile negatif yönde ilişkili olduğunu, devam bağlılığının ise hiçbir tükenmişlik boyutu ile ilişkili olmadığını saptamışlardır. Benzer sonuçlar farklı araştırmalarda da tekrarlanmıştır (Basami, vd., 2013).

Araştırmaların ancak çok küçük bir kısmı örgütsel bağl1lık ve tükenmişlik arasındaki ilişkilerde daha öteye geçip, bu iki değişken arasındaki etkileşimi incelemiştir. Reilly (1994) hemşireler üzerinde yaptığı araştırmada örgütsel bağlılığın tükenmişlik üzerinde negatif yönde etkili olduğunu tespit etmiştir. Tan ve Akhtar (1998) ise Çin'de yaptıkları araştırmada duygusal tükenmenin normatif bağl1lıktan etkilendiğini ortaya çıkarmışlardır. İki değişken arasındaki etkileşimi en ayrıntılı inceleyen araştırmalardan bir tanesi değişkenler arasındaki ilişkinin incelenmesi amacıyla ortaya konulmuş, fakat araştırmanın sonunda etkileşime de değinmiş olan Çetin ve arkadaşları (2011)'nın çalışmasıdır. Bu çalışma sonuçlarına göre örgütsel bağl1lık boyutlarından duygusal bağlılık ve devam bağlılığı tükenmişlik boyutlarının tamamı üzerinde etkili olurken, normatif bağl1lık sadece duygusal tükenme boyutu üzerinde etkili olmaktadır. Ayrıca duygusal bağlılık ve normatif bağl1lık tükenmişlik boyutları üzerinde negatif 
yönde etki yaparken, devam bağlılığının her üç tükenmişlik boyutu üzerinde de pozitif yönde etki yapması dikkat çekicidir.

Yazın taramasından da anlaşılacağ 1 gibi örgütsel bağlılık boyutlarının tükenmişlik boyutları üzerindeki etkisinin araştırıldığı çalışma sayısı oldukça sınırlıdır. Bu nedenle bu çalışmada bağlılık boyutlarının tükenmişlik boyutları üzerindeki etkileri araştırılmıştır.

\section{Araştırmanın Yöntemi}

\section{A. Örneklem}

Araştırmanın örneklemini Sakarya ili merkezinde bulunan bir özel sağlık kurumunda görev yapan 192 sağlık personeli oluşturmaktadır. Çalışmanın sağlık personeli üzerinde yürütülmesinin nedeni, daha önce kuramsal çerçevede de belirtildiği gibi sağlik personellerinin en fazla tükenmişlik yaşayan meslek grupları arasında yer almasıdır. Araştırma anketleri gönüllülük esasına göre ve kolayda örnekleme yöntemi ile 200 sağlı personeline dağıtılmış, geri dönen anket formlarından 192'si analize uygun bulunmuştur. Araştırmaya katılan sağlık personelinin yaş aralığı 18 ile 60 arasında olup, katılımcıların \%43.2'si 26-35 yaş grubunda yer almaktadır. \%59'u kadın olan katılımcıların, \%63'ü evlidir.

\section{B. Veri Toplama Aracları}

Örgütsel Bağlllık Ölçeği: Örneklemin örgütsel bağl1lık düzeyini belirlemek amacıyla Allen ve Meyer (1990) tarafından geliştirilmiş olan örgütsel bağl1lık ölçeği kullanılmıştır. Ölçek Türkçe'ye Wasti (1999) tarafindan uyarlanmıştır. Ölçek "Duygusal Bağlılık", "Devam Bağlılığı" ve "Normatif Bağlllık" olmak üzere üç boyut ve her bir boyutta 8 ifade olmak üzere toplam 24 ifadeden oluşmaktadır. Allen ve Meyer (1990) çalışmalarında örgütsel bağlılığın alt boyutları olan duygusal, devam ve normatif bağlılığa ilişkin Cronbach Alfa güvenilirlik katsayıları sırasıly $0.84,0.75$ ve 0.79 , Wasti (1999) tarafından yapılan araştırmadaki güvenilirlik katsayıları ise sırasıyla $0.84,0.80$ ve 0.70 olarak belirlenmiştir. Bu araştırmada ölçeğin alt boyutlarına ilişkin Cronbach Alfa güvenilirlik katsayıları duygusal bağlılık için 0.75 , devam bağl1lığ için 0.75 ve normatif bağll1ık için 0.84 olarak bulunmuştur.

Wasti (1999) tarafindan uyarlanan örgütsel bağl1lık ölçeğinin seçilen örneklem için yap1 geçerliliğini test etmek amaciyla LISREL paket programı kullanılarak doğrulayıcı faktör analizi yapılmıştır. Analiz sonucunda elde edilmiş olan değerler, araştırmada kullanılan örgütsel bağlılık ölçeğinin örneklem için yap1 geçerliliğine sahip olduğunu göstermektedir $\left(\mathrm{x}^{2} / \mathrm{df}=3.02, \quad \mathrm{SRMR}=0.05\right.$, $\mathrm{CFI}=0.95$, NNFI=0.94).

Maslach Tükenmişlik Ölçeği: Araştırmaya katılan personelin tükenmişlik düzeyini ölçmek için Maslach ve Jackson (1981) tarafından geliştirilmiş olan ve Ergin (1992) tarafindan Türkçe'ye uyarlanan Maslach Tükenmişlik Ölçeği kullanılmıştır. Toplam 22 ifadeden oluşan bu ölçek, tükenmişliği üç farklı boyut üzerinden ölçmektedir. Bu boyutlar ölçekte 9 ifade ile temsil edilen duygusal tükenme, 5 ifade ile temsil edilen duyarsılaşma ve 8 ifade ile temsil edilen kişisel başarı alt boyutudur. 
Maslach ve Jackson (1981)'ın çalışmasında tükenmişliğin alt boyutları olan duygusal tükenme, duyarsızlaşma ve kişisel başarı hissinde azalmaya ilişkin Cronbach Alfa güvenilirlik katsayıları sirasiyla 0.86, 0.72 ve 0.74, Ergin (1992) tarafından yapılan araştırmadaki güvenilirlik katsayıları ise sırasıyla $0.83,0.65$ ve 0.72 olarak belirlenmiştir. $\mathrm{Bu}$ araştırmada ölçeğin alt boyutlarına ilişkin Cronbach Alfa güvenilirlik katsayıları duygusal tükenme için 0.88 , duyarsızlaşma için 0.75 ve kişisel başarı hissinde azalma için 0.79 olarak bulunmuştur.

Bu araştırmada Ergin (1992) tarafından uyarlanan ölçeğin geçerliliği için doğrulayıcı faktör analizi yapılmış ve analiz sonucunda elde edilen değerlerin ölçeğin geçerliliği için yeterli kanıtı sağladığı değerlendirilmektedir $\left(\mathrm{x}^{2} / \mathrm{df}=2.89\right.$, SRMR=0.04, CFI=0.92, NNFI=0.91).

\section{Bulgular}

Analizin ilk aşamasında katılımcıların örgütsel bağlılık ve tükenmiş değişkenleri ve bu değişkenlerin alt boyutlarına ilişkin elde edilen verilerin ortalama, standart sapma ve değişkenlerin alt boyutları arasındaki korelasyonlara bakılmıştır. Araştırmada yer alan değişkenlere ilişkin elde edilen verilerin ortalama ve standart sapmaları ile korelasyon katsayıları Tablo 1'de görülmektedir.

Tablo 1. Değiş̧kenlere İlişkin Ortalama, Standart Sapma ve Korelasyon Katsayıları

\begin{tabular}{|c|c|c|c|c|c|c|c|c|}
\hline & & Ort. & S.S. & 1 & 2 & 3 & 4 & 5 \\
\hline 1 & Duygusal bağlılık & 3,22 &, 70 & & & & & \\
\hline 2 & Devam bağ l1lı̆̆ 1 & 2,67 &, 72 &,- 036 & & & & \\
\hline 3 & Normatif bağlilik & 2,78 &, 80 &, $666 * *$ &, $286 * *$ & & & \\
\hline 4 & Duygusal tükenme & 2,81 &, 83 &,$- 470 * *$ &, 062 &,$- 487 * *$ & & \\
\hline 5 & Duyarsızlaşma & 2,31 &, 80 &,$- 483^{* *}$ &, 140 &,$- 412 * *$ &, $755^{* *} *$ & \\
\hline 6 & Kişisel başarı & 3,59 & ,68 &, $474 * *$ &,$- 173 *$ &, $366 * *$ &,$- 394 * *$ &,$- 508 * *$ \\
\hline
\end{tabular}

*p $<0.05, * * \mathrm{p}<0.01$

Korelasyon analizi sonuçlarına göre duygusal bağl1lı ile duygusal tükenme $(\mathrm{r}=-0.470, \mathrm{p}<0.01)$ ve duyarsızlaşma $(\mathrm{r}=-0.483, \mathrm{p}<0.01)$ negatif yönde, kişisel başarı ise pozitif yönde $(\mathrm{r}=0.474, \mathrm{p}<0.01)$ ilişkilidir. Devam bağl1lı̆̆ tükenmişlik alt boyutlarından sadece kişisel başarı $(\mathrm{r}=-0.173, \mathrm{p}<0.05)$ negatif yönlü ilişkilidir. Normatif bağlllik ise duygusal tükenme $(\mathrm{r}=-0.487, \mathrm{p}<0.01)$ ve duyarsızlaşma $(\mathrm{r}=-0.412, \mathrm{p}<0.01)$ ile ters, kişisel başarı $(\mathrm{r}=0.366, \mathrm{p}<0.01)$ ile aynı yönde ilişkilidir.

Örgütsel bağlılık alt boyutlarının tükenmişlik alt boyutları üzerindeki etkisinde örneklemin demografik özellikleri açısından değişkenler arasında bir farklılık olup olmadığını tespit etmek amacıyla fark analizleri yapılmıştır. Öncelikle yapılan t testi sonucunda cinsiyet değişkeninin araştırmaya konu olan örgütsel bağlılık ve tükenmişlik alt boyutları üzerinde anlamlı bir farklılaşmaya neden olup olmadığı araştırılmıştır. Analiz sonucunda kadın ve erkek işgörenlerin sadece duygusal bağl1lık ve duygusal tükenme algıları arasında anlamlı bir 
farklılık olduğu belirlenmiştir $(\mathrm{p}<0.05)$. Buna göre erkek işgörenlerin daha yüksek düzeyde duygusal bağlılık yaşarlarken, kadın işgörenler daha fazla duygusal tükenme yaşamaktadırlar. Medeni durum açısından örneklem incelendiğinde evli işgörenlerin duygusal bağlılık düzeylerinin bekarlardan yüksek olduğu tespit edilmiştir. Sahip olunan çocuk sayısı açısından bakıldığında ise 1 tane çocuğu olanların hiç çocuğu olmayanlardan daha yüksek düzeyde duygusal bağlılık seviyesine sahip oldukları, hiç çocuğu olmayanların ise 1 ve 2 çocuğu olanlardan daha fazla duygusal tükenme algıladıkları tespit edilmiştir.

Örgütsel bağl1lık alt boyutlarının tükenmişliğin her bir alt boyutunu etki düzeyini tespit etmek amacıyla çoklu regresyon analizi yapılmıştır. Regresyon analizinde örnekleme ait cinsiyet, medeni durum ve çocuk sayısı değişkenleri birinci aşamada girilerek kontrol altına alınmıştır. İkinci aşamada ise örgütsel bağlılık alt boyutlarının tükenmişlik alt boyutları üzerindeki etkilerine bakılmıştır. İlk analizde örgütsel bağlılık alt boyutlarının tükenmişlik alt boyutlarından duygusal tükenme üzerindeki etkisine bakılmış, elde edilen değerler Tablo 2'de verilmiştir.

Tablo 2. Duygusal Tükenme Alt Boyutuna İlişkin Regresyon Analizi Sonuçları

\begin{tabular}{|c|c|c|c|c|}
\hline & $\beta$ & $\mathbf{R}^{2}$ & Düzeltilmiş $\mathbf{R}^{2}$ & $\mathbf{F}$ \\
\hline Duygusal Bağlılık & $-0.173^{*}$ & \multirow{3}{*}{0.344} & \multirow{3}{*}{0.322} & \multirow{3}{*}{$16.142 * *$} \\
\hline Devam Bağl1lı̆̆ 1 & $0.150^{*}$ & & & \\
\hline Normatif Bağl11ık & $-0.385 * *$ & & & \\
\hline
\end{tabular}
$* \mathrm{p}<0.05, * * \mathrm{p}<0.01$

Çoklu regresyon analizi sonuçlarına göre örgütsel bağl1lığın boyutları, tükenmişliğin duygusal tükenme alt boyutunu etkilemektedir. Bu etki duygusal ve normatif bağl1lık için negatif yönde, devam bağl1lı̆̆ için ise pozitif yöndedir. Diğer yandan üç örgütsel bağlılık alt boyutunun bir arada duygusal tükenme değişkenindeki varyansın \%32'sini açıkladıkları da tespit edilmiştir ( $\mathrm{F}=16.142$, $\mathrm{p}<0.01)$. Beta katsayılarına bakıldığında normatif bağlılığın duygusal tükenmenin en önemli yordayıcısı olduğu görülmektedir $(\beta=-0.385$, $p<0.01)$.

Örgütsel bağlılık alt boyutlarının duyarsızlaşma alt boyutu üzerindeki etkisini incelemek amacıyla ayrı bir regresyon analizi yapılmıştır. Analiz sonuçlarına Tablo 3'te görülmektedir.

Tablo 3. Duyarsızlaşma Alt Boyutuna İlişkin Regresyon Analizi Sonuçları

\begin{tabular}{|c|c|c|c|c|}
\hline & $\boldsymbol{\beta}$ & $\mathbf{R}^{2}$ & Düzeltilmiş $\mathbf{R}^{2}$ & F \\
\hline Duygusal Bağlılık & $-0.286^{* *}$ & \multirow{3}{*}{0.316} & \multirow{3}{*}{0.294} & \multirow{3}{*}{$14.276^{* *}$} \\
\hline Devam Bağl1lı̆̆ 1 & $0.193 * *$ & & & \\
\hline Normatif Bağl1lık & $-0.254 * *$ & & & \\
\hline
\end{tabular}

Tablo 3'te de görüldüğü gibi duygusal ve normatif bağl1lık duyarsızlaşmayı negatif yönde etkilerken, devam bağlılığı duyarsızlaşmayı pozitif yönde etkilemektedir. Üç örgütsel bağl1l1k alt boyutunun bir arada duyarsılaşma alt boyutunu açıklama oranı \%29'dur $(\mathrm{F}=14.276, \mathrm{p}<0.01)$. Örgütsel bağlılık alt boyutları arasında duyarsızlaşma üzerinde en fazla etkiye sahip olan alt boyutun ise duygusal bağl11ık olduğunu söylemek mümkündür $(\beta=-0.286, p<0.01)$ 
Çalışmada son olarak örgütsel bağl111k alt boyutlarının kişisel başarı alt boyutu üzerindeki etkisi incelenmiştir. Analiz sonuçlarını özetleyen tablo aşağıda görülmektedir.

Tablo 4. Kişisel Başarı Alt Boyutuna İlişkin Regresyon Analizi Sonuçları

\begin{tabular}{|c|c|c|c|c|}
\hline & $\beta$ & $\mathbf{R}^{2}$ & Düzeltilmiş $\mathbf{R}^{2}$ & $\mathbf{F}$ \\
\hline Duygusal Bağl1lık & $0.318^{* * *}$ & \multirow{3}{*}{0.271} & \multirow{3}{*}{0.247} & \multirow{3}{*}{$11.455^{* *}$} \\
\hline Devam Bağlılığ & $-0.221 * *$ & & & \\
\hline Normatif Bağl1lık & $0.215^{*}$ & & & \\
\hline
\end{tabular}

Kişisel başarı alt boyutu açısından bakıldığında, duygusal bağlılık ve normatif bağlılık kişisel başarı hissini pozitif yönde etkilerken, devam bağ l1lı̆̆ kişisel başarı hissini negatif yönde etkilemektedir. Üç örgütsel bağlılık alt boyutu bir arada kişisel başarı hissindeki varyansın yaklaşık \%25'lik kısmını açıklamaktadırlar. Kişisel başarı hissine en fazla etki yapan örgütsel bağl11ık alt boyutu ise duygusal bağl111ktır $(\beta=0.318, \mathrm{p}<0.01)$.

\section{Tartışma ve Sonuç}

Bu çalışmada örgütsel davranış yazını için büyük önem taşıyan örgütsel bağl1lık ve tükenmişlik kavramları arasındaki etkileşim bağlılık ve tükenmişlik kavramlarının alt boyutları bazında incelenmiştir. $\mathrm{Bu}$ inceleme yazında kabul görmüş ve sıkça kullanılmakta olan Allen ve Meyer (1990) tarafından ortaya konulmuş olan örgütsel bağlılık boyutları ile Maslach ve Jackson (1981) tarafından ortaya konulmuş olan tükenmişlik boyutları temel alınarak yapılımıştır.

Yazında çoğunlukla bu iki değişken ve/veya bu değişkenlerin alt boyutları arasındaki ilişkiler incelenmiştir. Bu çalışmada da öncelikle değişkenlerin alt boyutları arasındaki ilişkilere değinilmiştir. Buna göre duygusal bağlılık ve normatif bağl1lık ile duygusal tükenme ve duyarsızlaşma arasında negatif, kişisel başarı arasında ise pozitif yönlü ilişki tespit edilmiştir. Devam bağlılı̆̆ı alt boyutunun ise tükenmişlik alt boyutlarından sadece kişisel başarı hissi ile negatif yönlü ilişkili olduğu tespit edilmiştir. Elde edilen sonuçlar yazın ile paralellik göstermektedir (Çetin, vd., 2011; Güneş, vd., 2009; Chuo, 2003). Diğer yandan korelasyon analizi sonucunda elde edilen bulgular tükenmişliğin duygusal tükenme ve duyarsızlaşma alt boyutları ile kişisel başarı alt boyutunun farklı yönlerde olduğunu ispatlar niteliktedir.

Regresyon analizi sonucunda elde edilen bulgular ise işgörenlerin tükenmişlik düzeylerini azaltma yönünde daha sağlıklı bilgiler sunmaktadır. Analiz sonuçlarına göre duygusal ve normatif bağlılığın artması duygusal tükenme ve duyarsızlaşmanın azalmasına, kişisel başarı hissinin ise artmasına neden olmaktadır. Diğer yandan bir diğer örgütsel bağlllık alt boyutu olan devam bağlılığının artması ise tam tersine duygusal tükenme ve duyarsılaşmanın artmasına, kişisel başarı hissinin ise azalmasına neden olmaktadır. Bu sonuç yazındaki diğer araştırma sonuçları ile paralellik göstermektedir (Çetin, vd., 2011).

$\mathrm{Bu}$ sonuçlar 1 şığında örgüt çalışanlarının tükenmişlik düzeylerini düşürmek amacıyla örgütsel bağlılıktan yararlanmanın faydalı olacağını söylemek mümkündür. Ancak tükenmişlik üzerinde örgütsel bağlılık alt boyutlarının her 
birinin aynı yönde etki yapmadıkları görülmüştür. Buradan hareketle örgütsel bağl1lık alt boyutlarından duygusal bağlılık ve normatif bağl11ık olumlu ve faydalı bağlılık boyutları olup, tükenmişlik düzeyi üzerinde de azaltıcı etki yaparlarken, devam bağl1lığı oldukça farklı bir etkiye neden olmaktadır. İşgörenlerin devam bağlılık düzeylerinin artması onların duygusal tükenme ve duyarsızlaşma yaşamalarına ve kişisel başarı hislerinin düşmesine neden olmaktadır. Bu nedenle örgütteki lider ve yöneticiler ile insan kaynakları departmanlarına düşen görev, işgörenlerin örgüte bağlılıklarını bir mecburiyet olmaktan çıkarılıp, gönüllülük esasına dayalı ve aidiyet duygusu ile bağlılık haline getirmektir.

\section{KAYNAKÇA}

Allen, N. J. ve Meyer, J. P. (1990), "The Measurement and Antecedents of Affective, Continuance and Normative Commitment to the Organization", Journal of Occupational Psychology, Vol. 63, 1-18.

Aslan, D., Kiper, N., Karaağaoğlu, E., Topal, F., Güdük, M. ve Cengiz, Ö. S. (2005), Türkiye’de Tabip Odalarına Kayttl Olan Bir Grup Hekimde Tükenmişlik Sendromu ve Etkileyen Faktörler, Türkiye Tabip Odaları Birliği Yayınları, Ankara.

Basami, A., Chizari, M. ve Abbasi, E. (2013), "Investigating Relationship between Job Burnout and Organizational Commitment among Extension Workers in Kurdistan Province", International Journal of Humanities and Social Science Invention, 10(2), 63-67.

Boylu, Y., Elbeyi, P. ve Gücer, E. (2007), “Akademisyenlerin Örgütsel Bağlılık Düzeyleri Üzerine Bir Araştırma", Finans Politik \& Ekonomik Yorumlar Dergisi, Cilt 44, Sayı 511, s.55-74.

Campana, K. L. ve Hammoud, S. (2014), "Incivility form Patients and Their Families: Can Organizational Justice Protect Nurses from Burnout?", Journal of Nursing Management, in press.

Chuo, S. (2003), "The Relationship between Organizational Commitment and Burnout", Yayınlanmamış Doktora Tezi, Alliant International University, California School of Organizational Studies, Los Angeles.

Cordes, C. L., Dougherty, T. W. ve Blum, M. (1997), "Patterns of Burnout among Managers and Professionals: A Comparison of Models", Journal of Organizational Behaviour, 18(6): 685-701.

Çakar, D. N. ve Ceylan, A. (2005), "İş Motivasyonunun Çalışan Bağlılığı ve İşten Ayrılma Eğilimi Üzerindeki Etkileri”, Doğuş Üniversitesi Dergisi, Cilt 6, Say1 1, İstanbul, s.52-66.

Çetin, F., Basım, H. N. ve Aydoğan, O. (2011), "Örgütsel Bağlılığın Tükenmişlik ile İlişkisi: Öğretmenler Üzerine Bir Araştırma”, Selçuk Üniversitesi Sosyal Bilimler Enstitüsü Dergisi, 25, 61-70.

Demirel, Y. (2009), "Örgütsel Bağlılık ve Üretkenlik Karşıtı Davranışlar Arasındaki İlişkiye Kavramsal Yaklaşım”, İstanbul Ticaret Üniversitesi Sosyal Bilimler Dergisi, Cilt 8, No 15, İstanbul, s.115-132.

Ensari, H. ve Tuzcuoğlu, S. (1995), "Marmara Üniversitesi'ne bağlı Fakültelerde Görev Yapan Yönetici ve Öğretim Elemanlarının Meslekten Yılgınlıklarında Kişilik Özelliklerinin Rolü”, Öneri Dergisi, 2(11): 51-63.

Ensher, A. E., Grant-Vallone, E. J. ve Donaldson, S. I. (2001), "Effects of Perceived Discrimination on Job Satisfaction, Organizational Commitment, Organizational Citizenship Behavior and Grievances", Human Resource Development Quarterly, Vol 12, No 1, p.53-72.

Eren, E. (2010), Örgütsel Davranış ve Yönetim Psikolojisi, Beta Yayıncılık, 12. Baskı, İstanbul.

Ergin, C. (1992), "Doktor ve Hemşirelerde Tükenmişlik ve Maslach Tükenmişlik Ölçeği'nin Uyarlanması", 7. Ulusal Psikoloji Kongresi Bilimsel Çalışmaları, Hacettepe Üniversitesi, Ed.: R. Bayraktar ve İ. Dağ, Ankara, 143-154.

Ergin, C. (1995), “Akademisyenlerde Tükenmişlik ve Çeşitli Stres Kaynaklarının İncelenmesi”, Hacettepe Üniversitesi Edebiyat Fakültesi Dergisi, 12(1-2): 37-50.

Freudenberger, H. J. (1974), "Staff Burnout”, Journal of Social Issues, 30: 159-165. 
Göksel, A. Ve Aydıntan B. (2012), "Lider Üye Etkileşimi Düzeyinin Örgütsel Bağl1lık Üzerine Etkisi: Görgül Bir Araştırma", Süleyman Demirel Üniversitesi İktisadi ve İdari Bilimler Fakültesi Dergisi, 17(2), 247-271.

Gümüşlüoğlu, L. ve Aygün, Z. K. (2010), "Bilgi Çalışanlarının Adalet ve Güçlendirme Algılarının Örgüte, Lidere ve İşe Bağlılık Üzerindeki Etkileri”, Türk Psikoloji Dergisi, Cilt 25 Sayı 66, s.21-36.

Gündüz, B., Erkan, Z. ve Gökçakan, N. (2007), "Polislerde Tükenmişlik ve Görülen Psikolojik Belirtiler”, Çukurova Üniversitesi Sosyal Bilimler Enstitüsü Dergisi, 16(2), 283-298.

Güneş, İ., Bayraktaroğlu, S. ve Özen Kutanis, R. (2009), "Çalışanların örgütsel Bağl1lık ve Tükenmişlik Düzeyleri Arasındaki İlişki: Bir Devlet Üniversitesi Örneği”, Süleyman Demirel Üniversitesi İktisadi ve İdari Bilimler Fakültesi Dergisi, 14(3), 481-497.

Haley, G. R. (2003). "The Relationship between Burnout and Organizational Commitment in Academic Oncologists" Yayımlanmamış Doktora Tezi, Nova Southeastern University, Florida.

Karahan, A. (2008), "Çalı̧̧ma Ortamındaki Statü Farklılıklarının Örgütsel Bağl1lığa Etkisi”, Afyon Kocatepe Universitesi Sosyal Bilimler Dergisi, Cilt 10, Say1 3, Afyon, s.231-246.

Leiter, M. P. ve Maslach, C. (1988), "The Impact of Interpersonal Environment on Burnout and Organizational Commitment", Journal of Organizational Behavior, Vol. 9(4), 297-308.

Liu, H. (1996). "Burnout and Organizational Commitment Among Staff of Publicly Funded Substance Abuse Treatment Programs" Yayımlanmamış Doktora Tezi, University of Maryland, College Park, Maryland.

Maslach, C. ve Goldberg, J. (1998), "Prevention of Burnout: New Perspectives", Applied and Preventive Psychology, 7: 63-74.

Maslach, C. ve Jackson, S. E. (1986), Maslach Burnout Inventory Manual (2nd Ed.), Paulo Alto, Ca: Consulting Psychologist Press.

Maslach, C. ve S. E. Jackson (1981), “The Measurement of Experienced Burnout”, Journal of Occupational Behavior, 2: 99-113.

Maslach, C. ve Zimbardo, P. G. (1982), Burnout - The Cost of Caring, Prentice-Hall, Inc., Englewood Cliffs, New Jersey.

Maslach, C., Schaufeli, W. B. ve Leiter, M. P. (2001), "Job Burnout”, Annual Review Psychology, 52: 397-422.

Meyer, j. P. ve Allen, N. J. (1984), "Testing the "Side-Bet Theory" of Organizational Commitment: Some Methodogical Considerations", Journal of Applied Psychology, 69, 372-378.

Meyer, J. P. ve Allen, N. J. (1991), “A Three-Component Conceptualization of Organizational Commitment", Human Resource Management Review, 1, 61-89.

Meyer, J. P. ve Allen, N. J. (1997), Commitment in the Workplace, Sage, Thousand Oaks.

Morrow, P. C. (1983), "Concept Redundancy in Organizational Research, The Case of Work Commitment", Journal of Occupational Behavior, 34, ss. 40-56.

Mowday, R. T., Porter, L. W. ve Steers, R. M. (1982), Employee-Organizaton Linkages: The Psychology of Commitment, Absenteeism and Turnover, New York: Academic Press.

Obeng, K. ve Ugboro, I. (2003), "Organizational Commitment among Public Transit Employees: An Assessment Study", Journal of the Transportation Research Forum, 57(2), 83-89.

Reilly, N. P. (1994), "Exploring a Paradox: Commitment as a Moderator of the Stressor-Bunrout Relationship", Journal of Applied Social Psychology, 24(5), 397-414.

Shirom, A. (1989), Burnout in Work Organizations, (Eds.) C. L. Cooper ve I.T. Robertson, International Review of Industrial and Organizational Psychology, 25-48, New York, Wiley.

Silah, M. (2005), Endüstride Çalışma Psikolojisi, Seçkin Yayıncılık, 2. Baskı, Eskişehir.

Tan, D. S. K. ve Akhtar, S. (1998), "Organizational Commitment and Experienced Burnout: An Exploratory Study from a Chinese Cultural Perspective", The International Journal of Organizational Analysis, Vol. 6(4), 310-333.

Wasti, A. S. (1999). "Organizational Commitment in a Collectivist Culture: The Case of Turkey" Yayımlanmamış Doktora Tezi, University of Illionis, Urban-Illinois. 
S. Polatcı \& K. Ardıç \& G. Türkan / Bağlılık Boyutlarının Tükenmişlik Boyutları Üzerindeki Etkisinin Incelenmesi

Yılmazer, A. (2010), "Örgütsel Bağlılık ve Ekstra Rol Davranışı Arasındaki İlişkiler: İmalat Sektöründe Bir Araştırma”, Eskişehir Osmangazi Üniversitesi İktisadi ve İdari Bilimler Fakültesi Dergisi, Cilt 5, Sayı 2, Eskişehir, s.236-250. 